\title{
EFFECT OF DIETARY SUPPLEMENTATION OF TURMERIC (Curcuma longa) POWDER ON THE GROWTH PERFORMANCE AND CARCASS TRAITS OF BROILER CHICKS
}

\author{
M. A. Mondal, T. Yeasmin, R. Karim, M. Nurealam Siddiqui ${ }^{* 1}$ \\ S.M. Raihanun-Nabi ${ }^{2}$, M. A. Sayed ${ }^{3}$ and M.N.A. Siddiky ${ }^{4}$ \\ Department of Dairy and Poultry Science, Hajee Mohammad Danesh Science and Technology \\ University (HSTU), Dinajpur, Bangladesh
}

\begin{abstract}
The present study was aimed to investigate the dietary effect of different levels of turmeric (Curcuma longa) powder on the performance of broiler during summer (June-July), 2013. Four experimental rations designated as $\mathrm{T}_{0}, \mathrm{~T}_{1}, \mathrm{~T}_{2}$ and $\mathrm{T}_{3}$ having $0 \%, 0.5 \%, 1.0 \%$ and $1.5 \%$ Turmeric (Curcuma longa) powder were fed to 120 broiler chicks (Ross 308), randomly distributed into 12 replicates, so as to have 3 replicates per treatment and 10 chicks per replicate. Average weight gain, feed consumption, feed efficiency, dressing yield and survivability were used as criteria of response to feeding turmeric powder. Organs weight including heart, liver and gizzard were also recorded. The mean body weight gain and average feed efficiency (feed gain ${ }^{-1}$ ) per broiler significantly increased $(P<0.01)$ by turmeric supplemented feed compared to control feed. The average feed consumption and survivability of broiler chick non- significantly $(P>0.05)$ improved due to by turmeric supplementation in the diets. Inclusion of turmeric powder caused slightly increased the carcass traits of broiler chicks i.e., average weight of liver, heart and gizzard but the differences were non-significant $(P>0.05)$. A significant decrease $(P<0.01)$ in abdominal fat pad and significant increase $(P<0.05)$ in dressing yield was observed in chickens fed the turmeric supplemented diets. The results of the present study suggest that the use of turmeric (Curcuma longa) powder as feed
\end{abstract}

\footnotetext{
* Corresponding author email: nuralambmb@gmail.com

1 Department of Biochemistry \& Molecular Biology, Bangabndhu Sheikh Mujibur Rahman Agricultural University, Gazipur-1706, Bangladesh

2 Department of Biotechnology, Bangabndhu Sheikh Mujibur Rahman Agricultural University, Gazipur-1706, Bangladesh

3 Department of Biochemistry \& Molecular Biology, Hajee Mohammad Danesh Science and Technology University, Dinajpur-5200, Bangladesh

4 Senior Program Officer, SAARC Agriculture Centre, Dhaka, Bangladesh
}

Received: 22.02.2015 
additive at a level of $0.5 \%$ enhances the growth performances and carcass yield of broiler chicks.

Keywords: Turmeric powder, Performance, Carcass traits, Dressing Yield and broiler

\section{INTRODUCTION}

Poultry plays an important role in the economic development of the country. Bangladesh provides a very fertile and virgin field for the development of broiler industries. Broiler production has become a profitable and most popular income generating activity at present time for the people of the country. The broiler industry in Bangladesh is developing rapidly and its success depends on how rapidly a bird attains maximum marketable weight. The principle of poultry production is to achieve high level of performance through efficient utilization of feed keeping survivability as maximum as possible. The ultimate consumers of the end products of poultry are human beings and the major concern of all industries is the well being of the mankind. People of modern times are very much conscious about their health and quality of food items that they will consume. The term feed additive is applied in a broad sense, to all products other than those commonly called feedstuffs, which could be added to the ration with the purpose of obtaining some special effects (Feltwell and Fox, 1979).

The main objective of adding feed additives is to boost animal performance by increasing their growth rate, better-feed conversion efficiency, greater livability and lowered mortality in poultry birds. These feed additives are termed as "growth promoters" and often called as non-nutritive feed additives (Singh and Panda, 1992). Many synthetic drugs and growth promoters are supplemented to the broilers to have rapid growth, but their use have shown many disadvantages like high cost, adverse side effect on health of birds and long residual properties etc. Growth promoters are chemical and biological substances, which are added to livestock feed with the aim to improve the growth of chickens in fattening, improve the utilization of feed and in this way realize better production and financial results. Their mechanism of action varies. Positive effect can be expressed through better appetite, improved feed conversion, stimulation of the immune system and increased vitality, regulation of the intestinal micro-flora, etc. A variety of feed additives are being included in poultry diet to derive maximum growth of broiler chickens. Use of in-feed-antibiotics and hormones not only increases the cost of production but also leads to residues in meat and develops antibiotic resistance in microbes (Raghdad and Al-Jaleel, 2012).

Beneficial effects of bioactive plant substances in animal nutrition may include the stimulation of appetite and feed intake, the improvement of endogenous digestive enzyme secretion, activation of immune responses and antibacterial, antiviral and antioxidant actions (Toghyani et al., 2010 and 2011). 
The active ingredients found in Turmeric (Curcuma longa) are curcumin, demethoxy-curcumin, bisdemethoxycurcumin, (Wuthi-Udomler et al., 2000) and tetrahydrocur-cuminoids (Osawa et al., 1995). Plant extracts were found to have antifungal, (Wuthi-udomler et al., 2000) and anti- oxidative value (Osawa et al., 1995; Iqbal et al., 2003). Some pharmacological activities of Turmeric (Curcuma longa) as nematocidal (Kiuchi et al., 1993), hypolipidaemic (Ramirez-Tortosa et al., 1999) and anti-inflammatory (Ammon et al., 1993; Holt et al., 2005) were demonstrated. Curcumin has also been studied extensively as a chemo preventive agent in several cancers (Duvoix et al., 2005). Additionally, it has been suggested that curcumin possess hepatoprotective, antitumor, antiviral and anticancer activity (Polasa et al., 1991). It is used in gastrointestinal and respiratory disorders (Anwarul et al., 2006). Moreover Soni et al. (1997) proved the protective effects of Turmeric (Curcuma longa) as feed additives on aflatoxin-induced mutagenicity and hepatocarcinogenicity. In our previous study, we demonstrated that the medicinal plant herbs Nigella sativa, guava leaf meal, buckwheat, mulberry leaf and buckwheat supplemented feed improved growth performances and decrease serum cholesterol of poultry birds (Siddiqui et al., 2015; Islam et al., 2014; Rahman et al., 2013; Sayed et al., 2013; Islam et al., 2011). So, we are again concentrating on the use of our ancient medicinal system to find beneficial herbs and plants, which can be safely used to increase poultry production. Keeping this view in mind, the research was conducted to investigate the effect of feeding turmeric (Curcuma longa) powder on the growth performances and carcass characteristics of commercial broilers.

\section{MATERIALS AND METHODS}

\section{Layout of the experiment}

The experiment was conducted at the poultry shed under the Department of Dairy and Poultry Science, Hajee Mohammad Danesh Science and Technology University (HSTU), Dinajpur, Bangladesh during the period from 20 June to 11 July, 2013. A total 120 day-old broiler chicks (Ross 308) were purchased from CP Bangladesh Limited, Birampur, Dinajpur, Bangladesh.

The day-old chicks were reared at brooder house to adjust with the environmental condition up to 7 days. After 7 days, chicks were randomly allocated four dietary treatment groups of 30 chicks each; each treatment was composed of three replications with 10 birds.

\section{Collection, processing and preparation of the experimental diet}

Dried turmeric (Curcuma longa) rhizomes were purchased from local spices market of Dinajpur (Bangladesh). The samples were further ground into powder by machine at Bahadurbazar, Dinajpur, Bangladesh. The obtained powder was packed in a polythelene bag and preserved in the feed storage room until used for feed formulation. Loose feed was used throughout the experimental study. The experimental period was divided into two phases (broiler-starter and broiler-finisher). 
Broiler starter diet was provided between 0 and 14 days, and broiler finisher was fed from 15 to 28 days. Turmeric powder was incorporated into the experimental diets manually in appropriate doses. The composition of manually prepared experimental diets according to NRC, (1994) used in different treatments for the broiler is presented in Table 1. The experimental diets were designed as-

$$
\begin{array}{ll}
\mathrm{T}_{0}: & \text { control } \\
\mathrm{T}_{1}: & \text { control+ } 0.5 \% \text { turmeric powder } \\
\mathrm{T}_{2}: & \text { control+ } 1 \% \text { turmeric powder } \\
\mathrm{T}_{3}: & \text { control+ } 1.5 \% \text { turmeric powder }
\end{array}
$$

\section{Parameters studied}

The experimental birds were randomly assigned to diets and fed ad-libitium. During the experimental period (4-weeks), growth performance, body weight, live weight, feed efficiency of the birds were evaluated as described by Siddiqui et al. (2015). Feed conversion ratio (FCR) was calculated as the total feed consumption divided by weight gain in each replication. Survivability percentage was calculated as the total broilers survived divided by the number of starting birds multiplied by 100 .

At the end of the experiment one broiler was slaughtered from each replication to estimate dressing yield. Dressing yield is based on the relationship between the dressed carcass weight and live bird weight after things like the skin and internal organs have been removed. Dressing yield can be calculated by taking weight of the carcass divided by weight of live bird.

\section{Statistical analysis}

Data on different variables were subjected to analysis of variance (ANOVA) in a Completely Randomized Design (CRD), (Steel and Torrie, 1980). The significant differences between the treatment means were calculated by the Duncan's Multiple Range Test (DMRT). All analyses were performed by using MSTATC Program.

\section{RESULTS AND DISCUSSION}

\section{Effect of turmeric powder on body weight, feed intake, FCR and survivability}

Initial body weight of day-old broiler chicks fed on different dietary treatment was similar (Table 2). From 1 to 14 days of age, the highest $(358.10 \mathrm{~g})$ body weight gain was attained by broilers received turmeric powder at $0.5 \%(\mathrm{P}<0.05)$ and also from 15 to 28 days of age, the body weight gain was significant $(\mathrm{P}<0.01)$ in $0.5 \%$ (920.70g). During 1 to 28 days of age, the body weight gain (1279.0gm) in birds fed diet containing turmeric powder at level of $0.5 \%$ was significantly higher $(\mathrm{P}<0.01)$ followed by birds received $1.5 \%(1151.0 \mathrm{~g}), 1 \%(1137.0 \mathrm{~g})$ and $0 \%(1079.0 \mathrm{~g})$ turmeric powder. The significant increase in body weight in $0.5 \%$ turmeric powder may be due to optimum antioxidant activity of turmeric (Curcuma longa) at the level of $0.5 \%$ that can stimulate protein synthesis by bird's enzymatic system. The significant 
effect of turmeric powder on body weight was in agreement with the findings of some previous reports (Durrani et al., 2006; Raghdad and Al-Jaleel, 2012; Osawa et al., 1995; Samarasinghe et al., 2003; Wuthi-Udomler et al., 2000). They had found that inclusion of turmeric at the rate of $5 \mathrm{~g} \mathrm{~kg}^{-1}$ significantly increase body weight of broiler. But these findings contradict with the observation of Namagirilakshmi (2005), who stated that broiler fed on turmeric either at $0.25,0.50,0.75$ or $1 \%$ level did not significantly affect body weight gain.

Feed intake of broilers in different dietary treatments from 1 to 14 days of age was statistically significant $(\mathrm{P}>0.05)$ but during 15 to 28 days of age and also 1 to 28 days of experimental periods was almost statistically similar and the differences were non-significant $(\mathrm{P}>0.05)$ (Table 2). The above results were in agreement with some earlier studies (Nouzarian et al., 2001; Wuthi-Udomler et al., 2000). In those studies, feed intake of different broiler treatment did not differ significantly $(\mathrm{P}<0.05)$. However, the results of the present study disagreed with Raghdad and Al-Jaleel (2012) who found significant difference in feed consumption.

Feed conversion ratio (FCR) in different dietary treatments during the whole experimental period was statistically significant $(\mathrm{P}<0.01)$. At the end of the trial $(28$ days of age), the FCR was lowest in treatment $0.5 \%$ powder followed by $1.5 \%, 1.0 \%$ and $0.0 \%$ turmeric powder treated groups (Table 2) indicating that the best feed efficiency was due to optimum antioxidant activity of turmeric powder at the level of $0.5 \%$. Similar result was found by Durrani et al. (2006); Raghdad and Al-Jaleel (2012); Al-Sultan et al., (2003); and Wuthi-Udomler et al. (2000). They reported that broilers that received diet with $0.5 \%$ of turmeric powder utilized their diets more efficiently. However, Yaghobfar et al. (2011) stated that there was no significant effect of feeding turmeric powder on FCR at the level of 0.4 and $0.8 \%$.

Survivability of broilers fed on different dietary treatments was very high during the study period. The survivability did not vary significantly $(\mathrm{P}>0.05)$ among different treatment groups during the whole experimental period. Daneshyar et al. (2012) reported that addition of turmeric powder in broilers diets reduce the mortality rate due to ascites.

\section{Effect of turmeric powder on carcass traits}

Data on carcass characteristics and organ weights are presented in Table 3. This study showed that fat content of broiler was decreased significantly by supplementation of turmeric powder in broiler ration $(\mathrm{P}<0.01)$. Among different dietary treatments, amount of abdominal fat was lowest in $0.5 \%$ turmeric powder diet compared to control diet. These results agreed with some other researchers (Nouzarian et al., 2001; Al-Sultan et al., 2003), who reported lower fat content in broilers that fed diet containing $0.5 \%$ turmeric powder.

The non significant $(\mathrm{P}>0.05)$ effect of turmeric powder on the weight of internal organs (heart, liver and gizzard) of broilers fed experimental rations was in 
close agreement with the observation (Lal et al., 1999; Al-Sultan et al., 2003), who reported that feeding of turmeric did not alter the size of liver, gizzard, heart.

This study demonstrated significant $(\mathrm{P}<0.05)$ difference in dressing yield. The highest dressing yield was found in $0.5 \%$ turmeric powder supplemented diets compared to our control diets. Raghdad and Al-Jaleel (2012) used turmeric powder and found dressing percentage significantly increased by using $0 \%, 0.5 \%, 1.0 \%$ and $1.5 \%$, and turmeric powder, respectively.

\section{CONCLUSION}

Based on the results of the present study, it may be concluded that turmeric powder supplemented at a level of $0.5 \%$ has significant effect on body weight gain, FCR, abdominal fat content and dressing percentage of broiler, except feed intake and survivability. The results of the study also suggest that the supplementation of turmeric (Curcuma longa) powder at $0.5 \%$ level in diets has high potential as commercial applications for production performance of broiler. Therefore, turmeric powder can be used along with the other conventional feed ingredients.

\section{REFERENCES}

Al-Sultan, S.I. 2003. The effect of Curcuma longa (turmeric) on overall performance of broiler chickens. International Journal of Poultry Science, 3: 333-340

Ammon, H.P., Safayhi, H., Mack, T. and Sabieraj, J. 1993. Mechanism of anti-inflamm-atory actions of curcumin and boswellic acids. Journal of Ethnopharmacol, 38:113-119

Anwarul, H.G., Abdul, J., Muhammad, N. and Kashif, M. 2006. Pharmacological basis for the use of turmeric in gastrointestinal and respiratory disorders. Life Science, 76: 30893105

Daneshyar, M., Kermanshahi, H. and Golian, A. 2012.The effects of turmeric supplementation on antioxidant status, blood gas indices and mortality in broiler chickens with $\mathrm{T}_{3}$ induced ascites. British Poultry Science, 53:3, 379-385

Durrani, F.R., Ismail, M., Sultan, A., Suhail, S. M., Chand, N. and Durrani, Z. 2006. Effect of different levels of feed added turmeric (Curcuma longa) on the Performance of Broiler Chicks. Journal of Agriculture and Biological Science, 1:9-11

Duvoix, A., Blasius, R., Delhalle, S., Schnekenburger, M. and Morceau, F. 2005. Chemopreventive and therapeutic effects of curcumin. Cancer Letters, 223:181-190

Feltwell, R. and Fox, S. 1979. Practical poultry feeding. English Language Book Society Great Britain, 92-105

Holt, P.R., Katz, S. and Kirshoff, R. 2005. Curcumin therapy in inflammatory bowel disease: a pilot study. Digestive Diseases Science, 50:2191-2193

Iqbal, M., Sharma, S.D., Okazaki, Y., Fujisawa, M. and Okada, S. 2003. Dietary supplementation of curcumin enhances antioxidant and phase II metabolizing enzymes in ddY male mice: possible role in protection against chemical carcinogenesis and toxicity. Pharmacology and Toxicology, 92: 33-38 
Islam, M. R., Siddiqui, M. N., Khatun, A., Siddiky, M. N. A., Rahman, M. Z., Bostami, A. B. M. R., and Selim, A. S. M. 2014. Dietary effect of Mulberry leaf (Morus alba) meal on growth performance and serum cholesterol level of broiler chickens. SAARC Journal of Agriculture, 12(2): 79-89

Islam, M. T., Selim, A. S. M., Sayed, M. A., Khatun, M. A., Siddiqui, M. N., Alam, M. S., and Hossain, M. 2011. Nigella sativa L. supplemented diet decreases egg cholesterol content and suppresses harmful intestinal bacteria in laying hens. Journal of Animal and Feed Sciences, 20(4): 576-587

Kiuchi, F., Goto, Y., Sugimoto, N., Akao, N., Kondo, K. and Tsuda, Y. 1993. Nematocidal activity of turmeric: synergistic action of curcuminoids. Chemical and Pharmacological Bulletin, (Tokyo), 41: 1640-1643

Lal, B., Kapoor, A.K. and Asthana O.P. 1999. Efficiency of Curcumin in the management of chronic anterio- uveitis. Phytother Research, 13(4): 318-322

Namagirilakshmi, S. 2005. Turmeric (Curcuma longa) as nutraceutical to improve broiler performance. MSc, thesis submitted to Tamil Nadu Veterinary and Animal Sciences University, Chennai, India

Nouzarian, R., Tabeidian, S.A., Toghyani, M., Ghalamkari, G. and Toghyani, M. 2011. Effect of turmeric powder on performance, carcass traits, humoral immune responses, and serum metabolites in broiler chickens. Journal of Animal and Feed Science, 20: 389400

NRC, National Research Council (1994): Nutrient Requirements of Poultry. $9^{\text {th }}$ rev. ed. National Academy Press, Washington, DC, USA

Osawa, T., Sugiyama, Y., Inayoshi, M. and Kawakisi, S. 1995. Anti-oxidative activity of tetrahydrocurcuminoids. Biotechnology Biochemical, 59: 1609-1610

Polasa, K., Raghuram, T.C. and Krishna, T.P. 1991. Turmeric (Curcuma longa L.) induced reduction in urinary mutagens. Food Chemical and Toxicology, 29: 699-706

Raghdad, A. and Al-Jaleel, A. 2012. Use of turmeric (Curcuma longa) on the performance and some physiological traits on the broiler diets. The Iraqi Journal of Veterinary Medicine, 36 (1): 51-57

Ramirez-Tortosa, M.C., Mesa, M.D., Aguilera, M.C., Quiles, J.L. and Baro L. 1999. Oral administration of a turmeric extract inhibits LDL oxidation and has hypocholesterolemic effects in rabbits with experimental atherosclerosis. Atherosclerosis, 147: 371-378

Rahman, Z., Siddiqui, M.N., Khatun, M.A. and Kamruzzaman, M. 2013. Effect of guava (Psidium guajava) leaf meal on production performances and antimicrobial sensitivity in commercial broiler. Journal of Natural Products, 6:177-187

Samarasinghe, K., Wenk, C., Silva, K.F.S.T. and Gunasekera, J.M.D.M. 2003. Turmeric (Curcuma longa) root powder and mannanoligosaccharides as alternatives to antibiotics in broiler chicken diet. Asian-Australian Journal of Animal Science, $16: 1495-1500$

Sayed, M. A., Islam, M. T., Haque, M. M., Hossain Shah, M.J. and Hossain, M. A. 2013. Buckwheat supplemented diet suppresses serum triglycerides and increases high 
density lipoprotein in broilers for antibiotic free safe meat. Science Secure Journal of Biotechnology, 2 (1):26-35

Siddiqui, M.N., Islam, M. T., Sayed, M. A. and Hossain, M. A. 2015. Effect of dietary supplementation of acetone extracts of Nigella sativa L. seeds on serum cholesterol and pathogenic intestinal bacterial count in broilers. The Journal of Animal and Plant Sciences, 25(2): 372-379

Singh, K.S. and Panda, S. 1992. Feed additives. In: Poultry Nutrition. 2nd ed. Kalyani Publ. Dellu, pp. 134-143

Soni, K.B., Rajan, A. and Kuttan, R. 1997. Reversal of aflatoxin induced liver damage by turmeric and curcumin. Cancer Letters, 66:115-121

Steel, R.G.D. and Torrie, J.H. 1980. Principles and procedures of statistics: A Biometrical Approach. Mc Graw-Hill, New York

Toghyani, M., Toghyani, M., Gheisari, A.A., Ghalamkari, G. and Mohammadrezaei, M. 2010. Growth performance, serum biochemistry and blood hematology of broiler chicks fed different levels of black seed (Nigella sativa) and peppermint (Mentha piperita). Livestock Science, 129: 173-178

Toghyani, M., Toghyani, M., Gheisari, A.A.; Ghalamkari, G. and Eghbalsaeid, S. 2011. Evaluation of cinnamon and garlic as antibiotic growth promoter substitutions on performance, immune responses, serum biochemical and haematological parameters in broiler chicks. Livestock Science, 138:167-173

Wuthi-Udomlert, M., Grisanapan, W., Luanratana, O. and Caichompoo, W. 2000. Antifungal activity of Curcuma longa grown in Thailand. Southeast Asian Journal of Tropical Medicine Public Health, 31:178-182

Yaghobfar, A., Hosseini-Vashan, S. J., Golian, A., Nassiri, M. R and Raji, R. 2011. Evaluation of turmeric powder in diets based soybean oil on performance, energy and protein efficiency ratio and immune system of broiler chicks. Researches of the first International Conference, Babylon and Razi Universities 
Table 1. Composition of the experimental starter and finisher diets fed to broilers

\begin{tabular}{lcc}
\hline \multirow{2}{*}{ Feed ingredients } & \multicolumn{2}{c}{ Amount (kg/100kg feed) } \\
\cline { 2 - 3 } & Starter (1-14 days) & Finisher (15-28days) \\
\hline Maize & 53.5 & 57.00 \\
Rice polish (Auto) & 10.0 & 10.0 \\
Soybean meal (44) & 23.0 & 18.0 \\
Protein Concentrate (Jasoport) & 10.0 & 10.0 \\
Oyester shell & 1.0 & 0.75 \\
DCP(Di-calcium phosphate) & 0.5 & 0.75 \\
Soybean oil & 1.5 & 3.0 \\
Common salt & 0.25 & 0.25 \\
Vitamin- mineral- amino acid Premix & 0.25 & 0.25 \\
\hline Chemical Composition of experimental ration & & 3074 \\
\hline ME (KCal/kg) & 2977 & 19.40 \\
CP (\%) & 21.21 & 5.00 \\
CF (\%) & 5.00 & 0.95 \\
Ca (\%) & 1.00 & 0.75 \\
Available P (\%) & 0.74 & 6.00 \\
Ash (\%) & 6.00 & 0.89 \\
Lysine (\%) & 1.02 & 0.35 \\
Methionine (\%) & 0.35 & \\
\hline Virin-min & & \\
\hline
\end{tabular}

Vitamin-mineral-aminoacid premix was added @ $250 \mathrm{~g}$ per $100 \mathrm{~kg}$ which contained: vitamin A: $4800 \mathrm{IU}$; vitamin $\mathrm{D}: 960 \mathrm{IU}$; vitamin E: $9.2 \mathrm{mg}$; vitamin $\mathrm{k}_{3}: 800 \mathrm{mg}$; vitamin $B_{1}: 600 \mathrm{mg}$; vitamin $B_{2}: 2 \mathrm{mg}$; vitamin $B_{3}: 12 \mathrm{mg}$; vitamin $B_{5}: 3.2 \mathrm{mg}$; vitamin $\mathrm{B}_{6}: 1.8 \mathrm{mg}$; vitamin $\mathrm{B}_{9}: 2 \mathrm{mg}$; vitamin $\mathrm{B}_{12}: 0.004 \mathrm{mg}$; Co: $0.3 \mathrm{mg}$; $\mathrm{Cu}: 2.6$ mg; Fe: $9.6 \mathrm{mg}$; I: $0.6 \mathrm{mg}$; Mn: $19.2 \mathrm{mg}$; Zn: $16 \mathrm{mg}$; Se: $0.48 \mathrm{mg}$; DL - Methionine: $20 \mathrm{mg}$; L- lysine: $12 \mathrm{mg}$. 
Table 2. Performance of the broiler chickens fed the experimental diets

\begin{tabular}{|c|c|c|c|c|c|}
\hline \multirow{2}{*}{ Parameters } & \multicolumn{4}{|c|}{ Turmeric powder supplemented diets (\%) } & \multirow{2}{*}{$\begin{array}{l}\text { Level of } \\
\text { significance }\end{array}$} \\
\hline & 0.0 & 0.5 & 1.0 & 1.5 & \\
\hline $\begin{array}{l}\text { Initial body weight } \\
\left(\text { g bird }^{-1} \text { ) }\right.\end{array}$ & $39.67 \pm 0.333$ & $39.67 \pm 0.333$ & $39.00 \pm 0.577$ & $39.00 \pm 0.577$ & NS \\
\hline \multicolumn{6}{|l|}{$\begin{array}{l}\text { Feed } \\
\text { consumption(gbird } \\
{ }^{1} \text { ) }\end{array}$} \\
\hline 1-14 days & $467.10 \pm 6.30^{\mathrm{a}}$ & $417.30 \pm 11.05^{\mathrm{b}}$ & $438.30 \pm 11.30^{\mathrm{ab}}$ & $440.40 \pm 9.39^{\mathrm{ab}}$ & $*$ \\
\hline 15-28 days & $1532.59 \pm 30.26$ & $1379.38 \pm 34.92$ & $1452.09 \pm 43.31$ & $1414.45 \pm 0.80$ & NS \\
\hline $1-28$ days & $1999.74 \pm 33.92$ & $1796.68 \pm 41.97$ & $1890.43 \pm 54.52$ & $1854.89 \pm 40.55$ & NS \\
\hline Weight gain (g bird & $302.50 \pm 7.04^{\mathrm{b}}$ & $358.10 \pm 10.64^{\mathrm{a}}$ & $325.40 \pm 11.96^{\mathrm{ab}}$ & $336.50 \pm 8.32^{\mathrm{a}}$ & \\
\hline & $776.20 \pm 35.51^{\mathrm{b}}$ & $920.70 \pm 14.34^{\mathrm{a}}$ & $811.50 \pm 15.35^{\mathrm{b}}$ & $814.80 \pm 5.57^{\mathrm{b}}$ & * \\
\hline $\begin{array}{l}1-14 \text { days } \\
15-28 \text { days }\end{array}$ & $1079.00 \pm 41.70^{\mathrm{b}}$ & $1279.00 \pm 20.73^{\mathrm{a}}$ & $1137.00 \pm 27.19^{\mathrm{b}}$ & $1151.00 \pm 14.18^{\mathrm{b}}$ & $\begin{array}{l}* * \\
* *\end{array}$ \\
\hline 1-28 days & & & & & \\
\hline FCR & $1.55 \pm 0.049^{\mathrm{a}}$ & $1.17 \pm 0.035^{\mathrm{c}}$ & $1.35 \pm 0.053^{\mathrm{b}}$ & $1.31 \pm 0.038 \mathrm{~b}^{\mathrm{c}}$ & \\
\hline 1-14 days & $1.98 \pm 0.062^{\mathrm{a}}$ & $1.50 \pm 0.061^{\mathrm{c}}$ & $1.79 \pm .053^{\mathrm{b}}$ & $1.73 \pm 0.050^{\mathrm{b}}$ & $* *$ \\
\hline $\begin{array}{l}15-28 \text { days } \\
1-28 \text { days }\end{array}$ & $1.86 \pm 0.055^{\mathrm{a}}$ & $1.41 \pm 0.055^{\mathrm{c}}$ & $1.66 \pm 0.052^{\mathrm{b}}$ & $1.61 \pm 0.047^{\mathrm{b}}$ & $* *$ \\
\hline Survivability (\%) & $96.67 \pm 3.33$ & $93.33 \pm 3.33$ & $96.60 \pm 3.33$ & $93.33 \pm 3.33$ & NS \\
\hline
\end{tabular}

${ }^{\text {abc }}$ Figures in the row with similar superscripts alphabet did not differ significantly.

$* *=(\mathrm{P}<0.01), *=(\mathrm{P}<0.05), \mathrm{NS}=($ Non-significant $)$ 
Table 3. Effect of turmeric powder supplementation in diet of broiler on carcass traits at 28 days of age

\begin{tabular}{lccccc}
\hline \multirow{2}{*}{ Parameters(g) } & \multicolumn{4}{c}{ Turmeric powder supplemented diets (\%) } & \multirow{2}{*}{$\begin{array}{c}\text { Level of } \\
\text { significance }\end{array}$} \\
\cline { 2 - 5 } Abdominal fat & $\mathbf{0 . 0}$ & $\mathbf{0 . 5}$ & $\mathbf{1 . 0}$ & $\mathbf{1 . 5}$ & \\
\cline { 2 - 5 } & $2.50 \pm 1.00^{\mathrm{a}}$ & $1.31 \pm 0.090^{\mathrm{b}}$ & $1.35 \pm 0.090^{\mathrm{b}}$ & $1.62 \pm 0.115^{\mathrm{b}}$ & $* *$ \\
Heart & $8.60 \pm 2.30$ & $8.01 \pm 0.690$ & $8.30 \pm 0.150$ & $8.15 \pm 0.360$ & $\mathrm{NS}$ \\
Liver & $43.05 \pm 0.150$ & $42.90 \pm 0.100$ & $43.00 \pm 0.650$ & $43.08 \pm 0.790$ & NS \\
Gizzard & $37.60 \pm 1.40$ & $38.05 \pm 0.950$ & $37.50 \pm 0.695$ & $37.42 \pm .575$ & NS \\
$\begin{array}{l}\text { Dressing yield } \\
(\%)\end{array}$ & $57.00 \pm 0.20^{\mathrm{b}}$ & $61.00 \pm 0.500^{\mathrm{a}}$ & $58.00 \pm 0.50^{\mathrm{b}}$ & $59.00 \pm 1.00^{\mathrm{ab}}$ & $*$ \\
\hline
\end{tabular}

${ }^{a b c}$, Means in the same row with uncommon superscript differ significantly.

$* *=(\mathrm{P}<0.01), *=(\mathrm{P}<0.05), \mathrm{NS}=($ Non-significant $)$. 